\title{
The Role of Principal Leadership and Work Stress on Teacher Work Commitment
}

\author{
Siti Elsha Fauziah¹, Suryadi², Siti Zulaikha3
}

DOI: $10.35445 /$ alishlah.v13i1. 562

Article Info
Keywords:
Leadership
Work Stress
Work Commitment
Teacher

Kata kunci: Kepemimpinan Stres Kerja Komitmen Kerja Guru

\begin{abstract}
This study aims to determine the effect of principal leadership and work stress on the work commitment of extraordinary school teachers in North Jakarta. The method in this research uses a quantitative approach to multiple linear regression models. A sample test was conducted on 104 teachers of extraordinary schools in North Jakarta using the Slovin formula. Hypothesis testing is obtained from the t-test and the F-test. The results show that leadership has a positive and significant role in work commitment; job stress has a negative and effect on the work commitment where increased work stress will decrease teacher work commitment. Leadership and work stress affect the work commitment of teachers at special schools in North Jakarta with a coefficient of determination of 0,357 or $35,7 \%$, meaning that leadership and work stress simultaneously affect teacher work commitment by $35.7 \%$.
\end{abstract}

\begin{abstract}
Abstrak
Penelitian ini bertujuan untuk mengetahui pengaruh kepemimpinan kepala sekolah dan stress kerja terhadap komitmen kerja guru Sekolah Luar Biasa Jakarta Utara. Metodologi dalam penelitian ini menggunakan pendekatan kuantitatif dengan model regresi linier berganda. Dalam penelitian ini peneliti mengambil sampel sebanyak 104 guru dengan menggunakan rumus Slovin. Pengujian hipotesis didapat dari hasil uji-t dan uji-F. Hasil menunjukkan bahwa kepemimpinan memiliki pengaruh positif dan signifikan terhadap komitmen kerja guru; stres kerja berpengaruh negatif terhadap komitmen kerja guru SLB Jakarta Utara, dimana meningkatnya stres kerja akan membuat komitmen kerja guru menurun. Kepemimpinan dan stress kerja berpengaruh terhadap komitmen kerja guru SLB Jakarta Utara dengan nilai koefisien determinasi 0,357 atau 35,7\%, artinya, kepemimpinan dan stress kerja secara simultan memberikan pengaruh terhadap komitmen kerja guru sebesar 35,7\%.
\end{abstract}

\footnotetext{
${ }^{1}$ State University of Jakarta, Jakarta, Indonesia

Email: echafauziah@gmail.com

2 State University of Jakarta, Jakarta, Indonesia

Email: hcsuryadi.unj@gmail.com

${ }^{3}$ State University of Jakarta, Jakarta, Indonesia

Email: sitizulaikha@gmail.com
} 
In the world of education, success requires the cooperation of all stakeholders, including the government, parents, educators, and the environment. Additionally, among these various parties, the teacher's role is the most critical. Thus, it is necessary to pay attention to the commitment of teachers, which must continue to improve in light of future educational challenges to produce highquality human resources capable of competing in the global era. Quality refers to the degree to which something is good or bad or the level or degree to which something exists. This term is frequently used in business, engineering, and manufacturing to refer to techniques and concepts used to enhance a product or service quality. Poor quality planning results in market share loss, product failure, and waste, whereas good quality increases market share and a product's success. Thus, just as quality is an aspect that an organization must maintain, the State is an organization that must maintain education as one of its aspects. According to Mathis et al. (2016), organizational commitment refers to employees' belief in and ability to accept organizational goals and their desire to remain with the organization. Meanwhile, (Colquitt et al., 2017) define organizational commitment as the educator's desire to remain a part of the organization. According to Armstong (2020), organizational commitment is defined as a person's emotional attachment to an organization due to shared values.

Teachers are educators whose primary responsibility is to carry out educational activities that directly contribute to providing services in the communities in which they work. The teacher's primary responsibility is to provide the best possible service to students and, more broadly, to society. Thus, a teacher's creativity is critical; through their students' creativity, teachers will discover their potential and recognize their limitations. Of course, discovering these abilities cannot be separated from the utilization of God Almighty's grace (a gift of God) in the form of forward vision (foresight). (Sopian, 2016). This also applies to special education, where teachers must explore students' potentials beyond academic potential; of course, teachers of children with special needs face additional challenges.

Increased workloads, increased pressure requiring improved job skills, and extended working hours have contributed to increased job stress among an organization's employees (Wilhelm et al., 2004). Numerous studies in the literature address the issue of job stress in educational organizations, particularly among teachers. Numerous previous research studies have discovered, among others, that job stress has a significant negative effect on organizational commitment (Ngatimun et al., 2020). Additionally, research (Garg \& Dhar, 2014) examined the factors that affect employee commitment levels and their impact on India's quality. The findings indicate that organizational commitment serves as a robust mediator between (job stress) and its consequences (service quality). Stress on the job has a detrimental effect on organizational commitment. The purpose of this study was to examine the role of affective commitment in the relationship between organizational support perceptions, job stress, and intention to quit among employees in Ghana. The findings indicate that employee perceptions of organizational support affect employee intentions via job stress.

Additionally, work commitment acts as a moderator of the relationship between job stress and intention to leave. Along with job-related stressors, leadership can influence organizational commitment. In contrast, the effectiveness of a school organization is heavily influenced by the role of a guiding leader who guides members of the organization and group toward achieving the organization's goals, vision, and mission (Mosley \& Pieter, 2008). Additionally, Thomson stated that a leader's influence could have a social effect through a personal approach, authentic style, and two-way communication. A leader provides direction to his subordinates and subordinates so that his followers can later accept and implement the organization's goals and objectives.

Based on data collected from several state special schools, it illustrates the distribution of teacher-to-student ratios that do not comply with government regulations Article 24 Permendikbud No.17 of 2017, which states that Extraordinary Primary Schools (SDLB) have a 
maximum of 5 (five) students in a single class; and Extraordinary Middle Schools (SMPLB) and Special As can be seen from the ratios of teachers to students at several sample schools in North Jakarta, namely SLB Mawar Putih and SLBN o9 Jakarta, the ratio of teachers to students at the SD level is 1:7, while it is 1:10 at the SMP and SMA levels. Additionally, Dou et al. (2017) found that instructional and transformational leadership significantly affected teacher job satisfaction and organizational commitment, which was mediated by climate and teacher psychology. According to Pradhan and Jena (2017), transformational leadership and affective commitment are related. Transformational leadership has a positive effect on the commitment and performance of an organization. It is well established that practical commitment has a positive correlation with performance.

Stress has a detrimental effect on the human body (Von Glinow \& McShane, 2010). Numerous people suffer from back pain, tension, muscle pain, and other related problems, primarily due to muscle contraction caused by work-related stress (Newstrom, 2007). When employees are overworked, and under time constraints, they feel pressured and experience stress. This is frequently the result of management pressure, and poor management can contribute to job stress. Hulpia (2010) found it established a link between distributed leadership and teacher organizational commitment. in Interviews with secondary school teachers and principals were conducted. According to the research findings, differences in primary leadership practices can affect organizational commitment. These practices include effective and participative leadership, social interaction, teamwork, and decision-making. Teachers may report a higher level of commitment to school when principals are easily accessible, efficiently resolve conflicts, and empower teachers to participate in any school activity. Hulpia \& Devoa (2010) investigated the impact of cooperative, distributed, and participatory leadership on teacher organizational commitment. The cooperative, participative, and distributive leadership styles of discovery positively affect teacher organizational commitment.

This research focuses on examining the role of principal leadership and work stress on teacher work commitment. It is important to study because the principal, as the highest leader in the institution, has a crucial role in creating conducive conditions in the school that he/she leads.

\section{METHODS}

This study employed a survey technique in conjunction with a quantitative approach utilizing multiple linear regression techniques. The research sample was calculated using the Slovin formula with a $5 \%$ error rate, resulting in a proportionate random sampling technique of 104 North Jakarta Special School teachers. The researcher distributed the instruments to respondents before validating and certifying their reliability and validity. This study utilized a closed questionnaire that included 35 questions about leadership variables, 35 questions about work stress, and 35 questions about work commitment variables. Thus, there are 105 instrument research questions.

This study employed multiple linear regression techniques, which necessitated the performance of several pre-analysis tests, including the normality, significance, linearity, multicollinearity, and heteroscedasticity tests. Multiple linear regression models are used to ascertain the contribution of variables $\mathrm{X}_{1}$ and $\mathrm{X} 2$ to the dependent variable (Y). The hypothesis is tested using the t-test and the F-test. and the coefficient of determination to determine the influence of variables on one another, either partially or concurrently. The coefficient of determination test will also be used with this model because it indicates the degree to which the independent variables, namely leadership and work stress, affect the dependent variable, namely work commitment. SPSS version 26 was used to perform statistical calculations in this study.

The hypotheses in this study are: (1) principal leadership has a positive and significant effect on the work commitment of North Jakarta special school teachers; (2) Job stress has a negative and significant effect on the commitment of North Jakarta extraordinary school teachers, and (3) leadership and work stress have a combined and significant effect on the commitment of 
Al- Ishlah: Jurnal Pendidikan, June 2021, 13 (1), Pages 707-714

Siti Elsha Fauziah, Suryadi, Siti Zulaikha

teachers in North Jakarta extraordinary schools.

\section{FINDINGS AND DISCUSSION}

\section{Prerequisite Test Analysis}

1) Normality Test

By testing normality using the Kolmogorov-Smirnov formula and using SPSS version 26 in its calculations, Asymp.Sig (2-tailed ) the value is 0.090

Table 1. Kolmogoro-SmirnovNormality Test

\begin{tabular}{llr}
\hline & & $\begin{array}{c}\text { Unstandardized } \\
\text { Residual }\end{array}$ \\
\hline $\mathrm{N}$ & Mean & 104 \\
Normal Parameters ${ }^{\mathrm{a}, \mathrm{b}}$ & Std. & .0000000 \\
& Deviation & 15.44352098 \\
& Absolute & .081 \\
Most Extreme & Positive & .081 \\
Differences & Negative & -.066 \\
Test Statistic & & .081 \\
Asymp. Sig. (2-tailed) & & $.090^{\mathrm{c}}$ \\
\hline
\end{tabular}

It can be seen in the table above the Asymp value. Sig. the value is $0,090>0.05$. It can be concluded that the research data is normally distributed.

2) Linearity Test

Linearity is a test to prove a linear relationship between the independent and dependent variables. In this study, there are two independent variables, leadership (X1) and Job Stress (X2) and the dependent variable, Work Commitment (Y). This linearity test was calculated using application SPSS version 26, and the following results were obtained.

Table 2. Significance and Linearity Test: Leadership on the Work Commitment

\begin{tabular}{|c|c|c|c|c|c|c|c|}
\hline & & & $\begin{array}{c}\text { Sum of } \\
\text { Squares }\end{array}$ & dff & $\begin{array}{c}\text { Mean } \\
\text { Square }\end{array}$ & $\mathbf{F}$ & $\begin{array}{c}\text { Sig } \\
\text {. }\end{array}$ \\
\hline \multirow{5}{*}{$\begin{array}{l}\text { Commitment (Y) } \\
\text { * Leadership } \\
\text { (X1) }\end{array}$} & Btw.Groups & (Combined) & 22878.157 & 43 & 532.050 & 2.08 & .00 \\
\hline & & Linearity & 7944.863 & 1 & 7944.863 & $\begin{array}{r}6 \\
31.15 \\
4\end{array}$ & $\begin{array}{r}4 \\
.00 \\
0\end{array}$ \\
\hline & & $\begin{array}{l}\text { Deviation from } \\
\text { Linearity }\end{array}$ & 14933.294 & 42 & 355.555 & $\begin{array}{r}1.39 \\
4\end{array}$ & .117 \\
\hline & Within Groups & & 15301.189 & 60 & 255.020 & & \\
\hline & Total & & 38179.346 & 103 & & & \\
\hline
\end{tabular}

As can be seen from the SPSS output above, the significance of leadership (X1) on the Work Commitment variable $(\mathrm{Y})$ is 0.117 . Because $0.117>0,05$, a linear relationship exists between variables $\mathrm{X} 1$ and $\mathrm{Y}$.

Table 3.Significance and Linearity Tests: Job Stress on Work Commitment

\begin{tabular}{|c|c|c|c|c|c|c|c|}
\hline & & & $\begin{array}{l}\text { Sum of } \\
\text { Squares }\end{array}$ & df & $\begin{array}{c}\text { Mean } \\
\text { Square }\end{array}$ & $\mathrm{F}$ & Sig. \\
\hline \multirow{5}{*}{$\begin{array}{l}\text { Commitment (Y) } \\
\text { * Work Stress } \\
\text { (X2) }\end{array}$} & \multirow{3}{*}{$\begin{array}{l}\text { Between } \\
\text { Groups }\end{array}$} & (Combined) & 18387.707 & 45 & 408.616 & 1.197 & .257 \\
\hline & & Linearity & 6790.497 & 1 & 6790.497 & $\begin{array}{r}19.90 \\
0\end{array}$ & .000 \\
\hline & & $\begin{array}{l}\text { Deviation from } \\
\text { Linearity }\end{array}$ & 11597.210 & 44 & 263.573 & .772 & .813 \\
\hline & Within Groups & & 19791.639 & 58 & 341.235 & & \\
\hline & Total & & 38179.346 & 103 & & & \\
\hline
\end{tabular}

The results of the SPSS output in the table show that the significance value of the work stress (X2) on work commitment $(\mathrm{Y})$ is 0.813 . Because 0.813 is greater $(>) 0.05$, it can be concluded 
that there is a linear between work stress and work commitment variables.

3) Test Multicollinearity

Multicollinearity is used to determine whether there is a correlation between independent variables and the dependent variable. A good regression model is a model that does not have symptoms of multicollinearity with the condition that the tolerance value is $>0.10$ and the VIF value $<$ 10.00. After the multicollinearity test was carried out using SPSS version 26, the following results were obtained:

Table4. Multicollinearity -Test

\begin{tabular}{|c|c|c|c|c|c|c|c|c|}
\hline \multicolumn{2}{|c|}{ Model } & \multicolumn{2}{|c|}{$\begin{array}{l}\text { Unstandardized } \\
\text { Coefficients }\end{array}$} & \multirow{2}{*}{$\begin{array}{c}\text { Standardized } \\
\text { Coefficients } \\
\text { Beta }\end{array}$} & \multirow[t]{2}{*}{$\mathrm{t}$} & \multirow[t]{2}{*}{ Sig. } & \multicolumn{2}{|c|}{$\begin{array}{l}\text { Collinearity } \\
\text { Statistics }\end{array}$} \\
\hline & & B & $\begin{array}{l}\text { Std. } \\
\text { Error }\end{array}$ & & & & $\begin{array}{c}\text { Toleranc } \\
\mathrm{e}\end{array}$ & VIF \\
\hline \multirow[t]{3}{*}{1} & (Constant) & 115.034 & 14.632 & & 7.862 & .000 & & \\
\hline & $\begin{array}{l}\text { Leadership } \\
\text { (X1) }\end{array}$ & .438 & .083 & .424 & 5.296 & .000 & .993 & $\begin{array}{r}1.0 \\
07\end{array}$ \\
\hline & $\begin{array}{l}\text { Work Stress } \\
\text { (X2) }\end{array}$ & -.417 & .086 & -.387 & -4.828 & .000 & .993 & $\begin{array}{r}1.0 \\
07\end{array}$ \\
\hline
\end{tabular}

From the table above, it can be seen that the tolerance value is $0.993>0.10$. It means that there are no symptoms of multicollinearity in this study. In addition, decision making can also be done by looking at the VIF. Because the VIF value is $1.007<10.00$, it can be concluded that there are no symptoms of multicollinearity in this research.

\section{4)HeteroscedasticityThe Heteroscedasticity}

The test is used to determine that a regression model has a fixed residual value variant from one observation to another. The heteroscedasticity test in this study uses the Rank Spearman test based on decision-making if the value is significant or sig. (2-tailed) is greater than 0.05, so there is no heteroscedasticity. After calculating using SPSS version 26, the results are as follows:

Table 5. Heteroscedasticity - Test

\begin{tabular}{|c|c|c|c|c|c|c|}
\hline & \multirow[t]{2}{*}{ Model } & \multicolumn{2}{|c|}{$\begin{array}{l}\text { Unstandardized } \\
\text { Coefficients }\end{array}$} & \multirow{2}{*}{$\begin{array}{c}\text { Standardized } \\
\text { Coefficients } \\
\text { Beta } \\
\end{array}$} & \multirow[t]{2}{*}{$\mathrm{t}$} & \multirow[t]{2}{*}{ Sig. } \\
\hline & & B & Std. Error & & & \\
\hline \multirow[t]{3}{*}{1} & (Constant) & $7 \cdot 325$ & 7.406 & & .989 & .325 \\
\hline & $\begin{array}{l}\text { Leadership } \\
\text { (X1) }\end{array}$ & .076 & .042 & .178 & 1.819 & .072 \\
\hline & $\begin{array}{l}\text { Work Stress } \\
\text { (X2) }\end{array}$ & -.045 & .044 & -.100 & -1.023 & .309 \\
\hline
\end{tabular}

Based on the table above, the SPSS output the Sig. (2-tailed) for leadership is 0.072 greater ( $>$ ) than 0.05. Then, the Sig. (2-tailed) for work, stress is 0.309 greater ( $>$ ) than 0.05. Because the two obtained significance values are more significant than 0.05 , it can be concluded that there is no heteroscedasticity problem in this regression model.

\section{Multiple Linear Regression Analysis}

After being processed using SPSS version 26 to find a multiple linear regression model for this study. Then the following results are obtained:

Table 6. Multiple Linear Resression Test

\begin{tabular}{lc}
\hline \hline Variable & Regression Coefficient \\
\hline Constant & 115.034 \\
Leadership(X1) & 0,438 \\
Work Stress (X2) & $-0,417$ \\
\hline \hline
\end{tabular}

From the results in the table above it can be concluded that the regression equation model in this study is $=\mathrm{X}_{3}=115.034+0,438-0,417$. Then also has a coefficient of determination from 


\section{Table 7. Test Coefficients Determination}

\begin{tabular}{cccc}
\hline \hline $\mathrm{R}$ & RSquare & $\begin{array}{c}\text { Adjusted } \\
\text { RSquare }\end{array}$ & Std.eror \\
\hline 0,597 & 0,357 & 0,344 & 15.59568 \\
\hline
\end{tabular}

Based on the table above, it can be seen that the coefficient of determination of this regression equation has a value that shows how much influence the independent variable has on the dependent variable simultaneously. From these results, the coefficient of determination was 0,357 or $35.7 \%$. It means that the leadership variable (X1) and the work stress variable (X2) has a simultaneous influence on the work commitment variable (Y) by 35,7\%. Meanwhile, the other $64,3 \%$ are influenced by variables not examined by the researcher.

\section{Hypothesis}

1) T-test

Tabel 8. T-test

\begin{tabular}{lcc}
\hline \hline Variable & t-count & Sig \\
\hline Leadershipp (X1) & 5.296 & 0,000 \\
Work Stress (X2) & -4.828 & 0,000 \\
\hline
\end{tabular}

From the results obtained in the SPSS output above, it is known that leadership (X1) and work stress have a partial influence on work commitment. This is from the significance value of each independent variable. The significance of the leadership variable (X1) is 0.000 , which has a value less than 0.05. In addition value to the variable leadership (X1) is 5,296, bigger than the ttable (104), which is worth 1.66. So it can be concluded that leadership (X1) positively affects work commitment (Y). while the work stress variable (X2) with a significance value of 0.000 is also less than 0.05. Moreover, the value t of the work stress variable (X2) is $-4,828$ smaller than the $t$ table (104) of 1.66. The Sign negative shows the influence negatively between work stress and commitment variables.

2) F-Test

Table 8. F-Test

\begin{tabular}{lllcccc}
\hline Model & & $\begin{array}{l}\text { Sum of } \\
\text { squares }\end{array}$ & df & $\begin{array}{c}\text { Mean } \\
\text { Square }\end{array}$ & F & Sig. \\
\hline 1 & Regressio & 13613.605 & 2 & 6806.803 & 27.986 & .000 $^{\mathrm{b}}$ \\
& $\mathrm{n}$ & & & & \\
& Residual & 24565.741 & 101 & 243.225 & & \\
& Total & 38179.346 & 103 & & & \\
\hline
\end{tabular}

From the table above, it is known that leadership (X1) and job stress simultaneously affect work commitment. It can be seen from the significance value (Sig), which is equal to o.0oo, more diminutive than 0.05. In addition, conclusions can be shown by looking at the value of Fcount of 27,986, which is greater than F Table 3.09. From these results, it can be concluded that leadership (X1) and Job Stress (X2) simultaneously affect teacher work commitment. It can be seen from the significance value of the Sig. of 0.000 . The effect of these two variables is $35,7 \%$ on teacher work commitment. It is indicated by the value of $\mathrm{R}$ Square $=0.357$. So it can be concluded that leadership (X1) and job stress have a simultaneous and significant effect on the work commitment of North Jakarta Special School teachers, which means that this hypothesis research is accepted.

The results of this study are in line with research (Ruzungunde et al., 2016). Based on the results of this study, there is a significant influence between work stress and affective commitment. Odor (2019) states to determine the relationship between job stress and organizational 
commitment. The correlation for all variables included in the study shows that job stress significantly affects organizational commitment. The value of work stress turned out to be negative association with affective commitment. Asgari (2014) indicates a significant relationship between organizational commitment to leadership style at the $95 \%$ confidence interval, which means that hypothesis Ho is rejected at the $95 \%$ confidence interval. Thus, there is a direct and significant influence between organizational commitment and delegative leadership style. Luthan (2009) concludes that normative commitment feels that leaving their organization will have harmful consequences and feel guilty when leaving the organization.

Tambalean (2014) discovered results that contradicted those of the researchers. These findings suggest that work-related stress has a limited effect on employee performance. According to Kondalkar (2009), stress can be defined as a pattern of psychological and emotional reactions by an individual in response to internal and external demands. It defines stress as a response to both internal and external stimuli. According to Kumar and Krishnaraj (2018), participative leadership styles positively affect employee commitment, as evidenced by an accepted hypothesis and a significant beta value. The hypothesis establishes that organizational commitment is positively associated with participatory leadership style. To summarize, leadership is a process through which an individual can develop into a leader through ongoing activities that enable them to influence those they lead (followers) to accomplish organizational goals.

\section{CONCLUSION}

The findings of this study indicate that while leadership and work stress positively affect teacher work commitment. The variable work stress has a negative effect on teacher work commitment in North Jakarta. The principal of an extraordinary school in North Jakarta must pay close attention to the workload assigned to teachers in accordance with their duties and functions; additionally, the principal, as a leader in the school, must be able to provide excellent service to his subordinates by attending to the teacher's needs for increasing his work commitment. Additionally, schools must provide training to teachers in order to enhance their effectiveness. The principal must compensate teachers based on the workload assigned, motivating teachers to perform their duties and reduce work stress. The researcher recognizes in this study that there are still numerous shortcomings and weaknesses in the implementation of research in the field due to the researcher's limited time, energy, and financial resources. The researchers hope that the findings of this study can be used as input or a reference for future researchers who will discuss similar topics and can be combined with less carefully controlled variables in this study.

\section{REFERENCES}

Al-Daibat, B. (2017). Impact Of Leadership Styles In Organizational Commitment dr. Bassam aldaibat administrative and financial department, irbed college/ alpalqa applied university, jordan. Journal, international vol, management review centre, european uk, development, 5(5), 25-37.

Armstong, m. (2020). Handbook of performance management (6th editio). British library.

Asgari, m. R. (2014). The effect of leadership styles on employees commitment to services quality in bank melli branches. 3(12), 113-129.

Colquitt, j. A., lepine, j. A., \& wesson, m. J. (2017). Organizational behavior: improving performance and commitment in the workplace. In practice development in health care (sixth edit, vol. 4, issue 4). Mcgraw-hill. https://doi.org/10.1002/pdh.22

Dou, d., devos, g., \& valcke, m. (2017). The relationship between school autonomy gap, pricinpal leadership, teacher job satisfaction, and organization commitment. Educational management administration \& leadership, 6, 959-977.

Garg, s., \& dhar, r. L. (2014). Effects of stress, lmx and perceived organizational support on service quality: mediating effects of organizational commitment. Journal of hospitality and tourism 
Al- Ishlah: Jurnal Pendidikan, June 2021, 13 (1), Pages 707-714

Siti Elsha Fauziah, Suryadi, Siti Zulaikha management, 21, 64-75. https://doi.org/10.1016/j.jhtm.2014.07.002

Hulpia, h., \& devoa, g. (2010). 1 how distributed leadership can make a difference in teachers" organizational commitment? A qualitative study. Teaching and teacher education, 3, 1-36.

Kondalkar, V. (2009). Organization development. New age international.

Kumar, g. S., \& krishnaraj, r. (2018). Influence of leadership styles on employees `commitment to service quality. 11(1).

Luthan, F. (2009). Organizational behavior. In hospital administration. https://doi.org/10.5005/jp/books/10358_23

Mathis, r. L., jackson, j. H., valentine, s. R., \& patricia, m. (2016). Human resource management (fifteenth). Cengage learning.

Mosley, d. C., \& pieter, p. H. (2008). Supervisory management, the art of inspiring, empowering, and developing people (sevent edi). Thomson south western.

Newstrom, j. W. (2007). Organizational behavior: human behavior at work [perilaku organisasional: perilaku manusia di tempat kerja].

Ngatimun, musriati, t., suharsono, j., \& candra, s. D. (2020). Occupational stress as mediator of relationship between workload, emotional intelligence and teacher's performance in probolinggo regency. Owner, 4(1), 104. https://doi.org/10.33395/owner.v4i1.223

Odor, b. H. O. (2019). Ogwashi uku, delta state of nigeria. 19(1).

Pradhan, s., \& jena, l. K. (2017). Effect of abusive supervision on employee's intention to quit and the neutralizing role of meaningful work in indian it organizations. International journal of organizational analysis, 25(5), 825-838. https://doi.org/10.1108/ijoa-01-2017-1107

Raffie, d. S., azis, n., \& idris, s. (2018). Pengaruh kompetisi, gaya kepemimpinan, budaya kerja dan lingkungan kerja terhadap kepuasan kerja pegawai dan dampaknya terhadap kinerja pegawai kantor kementerian agama kabupaten aceh barat. Jurnal magister manajemen fakultas ekonomi dan bisnis unsyiah, 2(1), 36-45.

Ruzungunde, v. S., murugan, c., \& hlatywayo, c. K. (2016). The influence of job stress on the components of organisational commitment of health care personnel in the eastern cape province south africa. International business \& economics research journal (iber), 15(5), 219226. https://doi.org/10.19030/iber.v15i5.9780

Sopian, a. (2016). Tugas, peran, dan fungsi guru dalam pendidikan. Raudhah proud to be professionals : jurnal tarbiyah islamiyah, 1(1), 88-97. Https://doi.org/10.48094/raudhah.vii1.10

Tambalean, p. F. (2014). The effect of work stress and leadership styles on employee performance. Jurnal emba, 2(4), 301-308.

Von glinow, m. A., \& mcshane, s. L. (2010). Organizational behavior (5th editio). Mcgraw-hill.

Wilhelm, k., kovess, v., rios-seidel, c., \& finch, a. (2004). Work and mental health. Social psychiatry and psychiatric epidemiology, 39(11), 866-873. https://doi.org/10.1007/s00127-004-08697 